\title{
ANALISIS YURIDIS TERHADAP KEDUDUKAN WASIAT YANG DIDAFTARKAN (WAARMERKING) DAN DISENGKETAKAN OLEH PARA AHLI WARIS (Studi Putusan Mahkamah Agung Nomor: 493 K/AG/2017)
}

\author{
SITI SOLIHA CHAIRANI HARAHAP \\ sitisoliha@gmail.com
}

\begin{abstract}
Abstrak
Wasiat di dalam pandangan hukum Islam mempunyai kedudukan yang penting dan selalu didahulukan pelaksanaannya, tidak menutup kemungkinan adanya masalah atau sengketa, baik dari pihak penerima wasiat sendiri maupun ahli waris dari si pemberi warisan. Salah satu kasus yang timbul dari adanya sengketa pemberian harta kekayaan berdasarkan wasiat kepada ahli waris yang ditinggalkan dari pewaris almarhum Amir Mohammad (Amin Khan), sehingga munculah sengketa pembagian warisan Permasalahan yang dikaji meliputi 2 (dua) hal, yaitu: Bagaimana kedudukan wasiat terhadap hak waris para ahli waris, dan Bagaimana penyelesaian sengketa wasiat berdasarkan kasus putusan Mahkamah Agung nomor $49 \mathrm{~K} / \mathrm{AG} / 2017$. Tujuan penulisan tesis ini terbagi menjadi 2 (dua), yaitu Untuk mengetahui kedudukan wasiat terhadap hak para ahli waris dan Untuk mengetahui penyelesaian sengketa wasiat berdasarkan putusan Mahkamah Agung nomor $49 \mathrm{~K} / \mathrm{AG} / 2017$. Metode yang digunakan adalah yuridis normatif dengan pendekatan perundang-undangan dan pendekatan konseptual. Bahan hukum yang digunakan adalah bahan hukum primer, bahan hukum sekunder, dan bahan non hukum, kemudian dilanjutkan dengan analisis bahan hukum. Berdasarkan hasil penelitian bahwa kedudukan wasiat terhadap hak waris para ahli waris bahwa surat wasiat dapat dibuat dalam dua cara yakni dinotariskan atau di bawah tangan. Surat wasiat yang dinotariskan (akta wasiat) akan didaftarkan pada Daftar Pusat Wasiat di bawah Kementerian Hukum dan Hak Asasi Manusia. Kekuatan hukum akta wasiat ini tidak dapat dibatalkan secara sepihak melainkan harus melalui putusan pengadilan. Wasiat yang melalui akta wasiat lebih menjamin secara hukum, baik bagi yang mengeluarkan wasiat maupun bagi yang menerima wasiat. Mahkamah Agung terdapat cukup alasan untuk mengabulkan permohonan kasasi yang diajukan oleh Para Pemohon Kasasi, Amsher Khan Mohamad, membatalkan Putusan Pengadilan Tinggi Agama Gorontalo Nomor 06/Pdt.G/2016/PTA.Gtlo, tanggal 7 Desember 2016 Masehi bertepatan dengan tanggal 7 Rabiulawwal 1438

Hijriah. Saran penulis kepada para pihak bahwa pembagian harta berdasarkan wasiat, harus segera dilaksanakan setelah pewasiat meninggal agar tidak menjadi bibit masalah antar keluarga ataupun orang lain. Bagi hakim selayaknya memutus perkara waris mencerminkan rasa keadilan hukum.
\end{abstract}

Kata Kunci: Ahli Waris, Wasiat.

Abstract
The writing of this thesis is basically motivated by the dissatisfaction of inheritance in
obtaining assets based on a will. Testaments often cause problems that often arise
because of one of the heirs who is dissatisfied with the distribution of inheritance or the
will he receives. Testament in the view of Islamic law has an important position and
always takes precedence over implementation, does not rule out the possibility of 
Otentik's: Jurnal Hukum Kenotariatan (Vol 2, No. 2, Juli 2020)

p-ISSN 2655-5131 e-ISSN 2685-3612

problems or disputes, both from the recipient of his own will and the heirs of the giver of the inheritance. One of the cases arising from the dispute over the provision of assets was based on a will to the beneficiary who was left behind from the heir of the deceased Amir Mohammad (Amin Khan), resulting in an inheritance distribution dispute. Based on this, the problems to be studied include 2 (two) things, namely: How is the position of the will against the inheritance rights of the heirs, and How to settle a testamentary dispute based on the case of the Supreme Court's decision number 49 K/AG/2017. The purpose of this thesis is divided into 2 (two), namely to determine the position of the will against the rights of the heirs and to find out the settlement of a will based on the decision of the Supreme Court number 49 K/AG/2017. The method used is normative juridical approach to legislation and conceptual approach. Legal materials used are primary legal materials, secondary legal materials, and non-legal materials, then proceed with analysis of legal materials. Based on the results of the study that the position of the will against the inheritance rights of the heirs that the will can be made in two ways, namely notarized or underhanded. The notarized will (will) will be registered in the List of Testament Centers under the Ministry of Law and Human Rights. The legal strength of this will is irrevocable but must go through a court ruling. A will through a will will guarantee more legally, both for those who issue a will and for those who receive a will. The Supreme Court has enough reasons to grant a cassation request submitted by the Cassation Appellant, Amsher Khan Mohamad, cancel the Decision of the Gorontalo Religious High Court Number 06/Pdt.G/2016/PTA.Gtlo, on December 7, 2016 to coincide with the 7th of Rabiulawwal 1438 Hijri. The author's advice to the parties is that the distribution of assets based on a will, must be immediately implemented after the deceased dies so as not to be the seed of problems between families or other people. For judges, it is appropriate to decide on inheritance cases to reflect a sense of legal justice.

Keywords: Heirs, Testaments.

\section{PENDAHULUAN}

Apabila dilihat dari segi etimologi, wasiat mempunyai beberapa arti yaitu menjadikan, menaruh kasih sayang, menyuruh dan menghubungkan sesuatu dengan sesuatu yang lain. Secara umum, kata wasiat disebutkan dalam Al-Qur'an sebanyak 9 kali, dalam bentuk kata kerja disebut sebanyak 14 kali, dalam bentuk kata benda jadian sebanyak 2 kali. Hal yang berhubungan dengan wasiat ini seluruhnya disebut dalam AlQur'an sebanyak 25 kali. Secara terminologi, para ahli hukum Islam mengemukakan bahwa wasiat adalah pemilikan yang disandarkan pada orang yang menyatakan wasiat meninggal dunia dengan jalan kebaikan tanpa menuntut imbalan atau tabarru. Jika diperhatikan dari segi asal kata, perkataan wasiat berasal dari bahasa Arab, kata wasiat berasal dari kata "washshaitu asy-syaia, uushii, artinya aushaltuhu (aku menyampaikan sesuatu). ${ }^{1}$

\footnotetext{
${ }^{1}$ Sayid Sabiq, Fikih Sunnah, Bandung : PT. Al-Ma'arif, 1988, hlm. 215.
} 
Berbagai hal yang masih memerlukan penjelasan, baik yang bersifat menegaskan ataupun yang bersifat merinci, disampaikan Rasulullah SAW melalui hadistnya. Walaupun demikian, penerapannya masih menimbulkan wacana pemikiran dan pembahasan di kalangan pakar hukum Islam yang kemudian dirumuskan dalam bentuk ajaran yang bersifat normatif. ${ }^{2}$ Aturan tersebut yang kemudian ditulis dan diabadikan dalam lembaran kitab fikih serta menjadi pedoman bagi umat muslim dalam menyelesaikan permasalahan yang berkenaan dengan hukum warisan dan wasiat.

Masalah warisan dan wasiat seringkali menimbulkan masalah dalam kehidupan sehari-hari. Masalah ini sering kali muncul karena adanya salah satu ahli waris yang merasa tidak puas dengan pembagian warisan yang diterimanya. Hal ini timbul dari sifat serakah manusia yang berkeinginan untuk selalu mendapatkan yang lebih dari apa yang telah diperolehnya. Begitu juga dengan wasiat, walaupun di dalam pandangan hukum Islam wasiat mempunyai kedudukan yang penting dan selalu didahulukan pelaksanaannya, tidak menutup kemungkinan adanya masalah atau sengketa, baik dari pihak penerima wasiat sendiri maupun ahli waris dari si pemberi warisan. ahli waris dari si pemberi warisan. ${ }^{3}$

Hukum waris di Indonesia secara umum masih menggunakan 3 (tiga) landasan hukum, yaitu:

1. Hukum waris berdasarkan hukum islam,

2. Hukum waris berdasarkan hukum adat,

3. Hukum waris berdasarkan hukum barat (BW). ${ }^{4}$

Berbicara mengenai hukum waris dalam Islam, hukum waris Islam itu sendiri menduduki tempat amat penting dalam Hukum Islam. Ayat- ayat Al Qur'an mengatur hukum waris dengan jelas dan terperinci yang tercantum pada surat surat Anisa' ayat 7,8,11,12,33 dan 176, surat Al-Baqarah ayat 180,233 dan 240, surat Al Anfal ayat 75, surat Al Ahzab ayat 4,5 dan 6 serta surat Ath Thalaaq ayat 7, kemudian dilengkapi juga oleh Sunah Nabi dan Ijtihad. Hal ini dapat dimengerti sebab masalah warisan pasti dialami oleh setiap orang. Sedemikian pentingnya kedudukan hukum waris Islam dalam hukum Islam dapat disimpulkan dari hadits Nabi riwayat Ibnu Majah dan Darru Quthni sebagaimana dikutip Mukhlis Lubis yang menyatakan bahwa "Pelajarilah

\footnotetext{
${ }^{2}$ Sayid Sabiq, Fikih Sunnah, Bandung: PT. Al-Ma'arif, 1990, hlm. 220-223

${ }^{3}$ Amir Syarifudin, Hukum Kewarisan Islam, Jakarta: Prenada Media, 2004, hlm. 295

${ }^{4}$ Masjfuk Zuhdi, Masail Fiqhiyah (Kapita Selekta Hukum Islam), Jakarta : PT. Gunung Agung, 1996, hlm. 195
} 
faraidh (hukum waris) dan ajarkanlah kepada manusia (orang banyak), karena dia (faraidh) adalah setengah ilmu dan dia (faraidh) mudah dilupakan serta merupakan ilmu yang pertama kali hilang dari umatku". ${ }^{5}$ Demikian pentingnya hukum kewarisan islam karena sangat erat kaitannya dengan ruang lingkup kehidupan manusia, bahwa setiap manusia akan mengalami peristiwa yang merupakan peristiwa hukum yang lazim disebut "meninggal dunia". 6

Hukum Waris menurut Pasal 171 (a) Kompilasi Hukum Islam (KHI) adalah "Hukum yang mengatur tentang pemindahan hak kepemilikan harta peninggalan (tirkah) pewaris, menentukan siapa yang berhak menjadi ahli waris dan berapa bagiannya masing-masing. ${ }^{7}$ Sedangkan menurut M. Hasballah Thaib memberikan definisi Hukum Kewarisan Islam adalah hukum yang mengatur segala sesuatu yang berkenaan dengan peralihan hak dan kewajiban atas harta, kekayaan seseorang yang telah meninggal dunia kepada ahli warisnya. Hukum kewarisan ini juga disebut hukum Faraidh yang bersumber Al-Quran, sunah dan ijtihad. ${ }^{8}$

Pembagian tersebut bagi masing-masing ahli waris baik itu laki-laki maupun perempuan telah ditetapkan ketentuannya di dalam Al-Quran. Setelah pewaris meninggal dunia, sebagaimana diatur dalam KHI yang membebankan beberapa kewajiban dan tanggung jawab kepada ahli waris. Adapun kewajiban dan tanggung jawab tersebut diatur dalam Pasal 175 KHI yang menentukan bahwa:

(1) Kewajiban sesama ahli waris terhadap ahli waris lainnya adalah :

a. Mengurus dan menyelesaikan sampai pemakaman jenazah

b. Menyelesaikan hutang piutang baik pengobatan, perawatan termasuk kewajiban pewaris maupun menagih hutang

c. Menyelesaikan wasiat pewaris

d. Membagi harta warisan diantara ahli waris yang berhak.

(2) Tanggung jawab ahli waris terhadap hutang atau kewajiban pewaris hanya terbatas pada jumlah atau nilai harta peninggalan. ${ }^{9}$

${ }^{5}$ Mukhlis Lubis, Ilmu Pembagian Waris, Pesantren Al Manar, Medan, 2011, hlm 4.

${ }^{6}$ Idris Ramulyo, Hukum Kewarisan Islam (Studi Kasus Perbandingan Ajaran Syafi'IPatrilineal-Hazairin-Bilateral-dan Praktek di Pwngadilan Agama, Ind Hill Co, 2010, hlm. 1

${ }^{7}$ Pasal 171 (a) Instruksi Presiden R.I Nomor 1 Tahun 1991 tentang Kompilasi Hukum Islam

${ }^{8}$ M. Hasballah Thaib, Ilmu Hukum Waris Islam, Medan: MKn USU, 2009, hlm.1

${ }^{9}$ Pasal 175 Instruksi Presiden R.I Nomor 1 Tahun 1991 tentang Kompilasi Hukum Islam 
Wasiat adalah suatu tashrruf (pelepasan) terhadap harta peninggalan yang dilaksanakan sesudah meninggal dunia yang berwasiat. Asalnya wasiat merupakan suatu perbuatan yang dilakukan dengan kemauan hati dalam keadaan apapun. ${ }^{10}$ Secara terminologi wasiat adalah pemberian seseorang kepada orang lain baik berupa barang, piutang atau manfaat untuk dimiliki oleh orang yang diberi wasiat sesudah orang yang berwasiat mati. ${ }^{11}$

Sedangkan pengertian wasiat menurut Pasal 171 (f) KHI adalah pemberian suatu benda dari pewaris kepada orang lain atau lembaga yang akan berlaku setelah pewaris meninggal dunia. ${ }^{12}$ Dengan kata lain wasiat adalah pesan seseorang mengenai penggunaan atau pemanfaatan harta peninggalannya. Kelak setelah ia meninggal dunia, baik wasiat itu untuk anggota kerabatnya ataupun bukan. Wasiat tersebut dilaksanakan atas dasar kemauan sendiri, tanpa paksaan oleh sebab itu wasiat yang dilakukan dengan jalan putusan hakim tidak dibenarkan. ${ }^{13}$

Wasiat merupakan salah satu cara yang digunakan untuk mendekatkan diri kepada Allah SWT pada akhir kehidupan seseorang agar kebaikannya bertambah, karena dalam wasiat terdapat kebaikan. Karena bersedekah pada saat hidup saja merupakan kebaikan, maka bersedekah setelah ia meninggal juga termasuk kebaikan. Disyari'atkannya wasiat berdasarkan Al-Quran dan sunnah. Dalam Al-Quran Surat AlBaqarah ayat 180 Allah SWT berfirman:

"Diwajibkan atas kamu, apabila seorang diantara kamu kedatangan tandatanda maut, jika dia meninggalkan harta yang banyak, berwasiat untuk ibu bapaknya dan karib kerabatnya secara ma'ruf. Ini adalah kewajiban atas orangorang yang bertaqwa." 14

Di sisi lain bagi pihak yang mendengarkan atau menerima wasiat, diharuskan bersikap jujur dan adil. Oleh karena jika orang-orang tersebut dengan sengaja mengubah isi wasiat, maka hal ini akan menghalangi tercapainya maksud

\footnotetext{
${ }^{10}$ Muhammad Ali as Shabuni, Hukum Waris Dalam Syariat Islam, Bandung: CV Diponegoro, 2010 , hlm 47.

${ }^{11}$ Asyhari Abta, Djunaidi Syakur, Ilmu Waris Deskripsi Islam Praktis Dan Terapan, Surabaya: Pustaka Hikmah Perdana, 2005, hlm. 65.

${ }^{12}$ Pasal 171(f) Instruksi Presiden R.I Nomor 1 Tahun 1991 tentang Kompilasi Hukum Islam

${ }^{13}$ Hasniah Hasan, Hukum Warisan Dalam Islam, Jakarta: PT. Bina Ilmu, 2000, hlm. 50

${ }^{14}$ Departemen Agama RI, Al-Qur'an danTterjemahan, Bandung: CV Diponegoro, 2010, hlm. 34
} 
baik dari pewasiat dan akan menanggung dosa atas perbuatannya tersebut. Dalam tafsir dijelaskan bahwa makna bil ma'ruf adalah wasiat itu dilakukan dengan cara yang tidak menyusahkan ahli waris, yakni tidak berlebihan dan tidak pula terlalu pelit. ${ }^{15}$ Pemberian wasiat itu harus adil dan tidak boleh melebihi sepertiga bagian dan juga tidak boleh berwasiat kepada orang kaya sedangkan meninggalkan orang yang faqir. ${ }^{16}$

Sedangkan menurut KHI dasar hukum dari wasiat yang diatur dalam Pasal 194 sampai dengan Pasal 209 menyatakan antara lain :

1. Wasiat hanya boleh dilakukan oleh orang yang telah dewasa dan berumur sekurangnya 21 (dua puluh satu) tahun, berakal sehat dan tanpa adanya paksaan dapat mewasiatkan sebagian harta bendanya kepada orang lain atau lembaga.

2. Harta benda yang diwasiatkan harus merupakan hak dari pewaris dan dilakukan secara lisan dihadapan 2 (dua) orang saksi atau tertulis dihadapan dua orang saksi atau di hadapan Notaris.

3. Wasiat hanya diperbolehkan sebanyak-banyaknya $1 / 3$ (sepertiga) dari harta warisan kecuali apabila semua ahli waris menyetujui.

Dalam Hukum Islam syarat-syarat wasiat harus mengikuti rukun-rukunnya. Apabila salah satu rukun wasiat tidak dapat dipenuhi maka wasiat tidak akan bisa dilaksanakan. Rukun wasiat tersebut, antara lain:

1. Harus ada orang yang berwasiat (mishi);

2. Harus ada seseorang atau badan hukum yang menerima wasiat (musha-lahu) dan ada orang yang menerima wasiat (musha-lahu);

3. Sesuatu yang diwasiatkan (musha-bihi);

4. Lapaz/ucapan wasiat (sighat) ${ }^{17}$

Terkait dengan orang yang dapat menerima wasiat para ulama sepakat bahwa orang-orang atau badan yang menerima wasiat adalah bukan ahli waris dan secara hukum dapat dipandang sebagai cakap untuk memiliki sesuatu hak atau benda. Hal itu sejalan dengan peraturan KHI pada Pasal 171 huruf f, Pasal 194 (1). Riwayat dari Abu Umamah

${ }^{15}$ H. Salim Bahreisy, H sahid Bahreisy, Terjemah Tafsir Ibnu Katsir, Jilid 1, Surabaya: PT. Bina Ilmu,2002, hlm. 337 hlm. 329

${ }^{16}$ Ismail Haqiy Al-Burusawa, Tafsir Ruhul Bayan Juz 1, Lebanon: Dar al Fiqr, 2006,

${ }^{17}$ Amir Syarifuddin, Pelaksanaan Hukum Kewarisan Islam Dalam Lingkungan Adat Minangkabau, Jakarta: PT. Gunung Agung, 1990, hlm. 66 
berkaya bahwa ia mendengar Rasulullah SAW bersabda dalam kutbah tahun haji wada': "Sesungguhnya Allah telah memberikan kepada orang yang mempunyai hak akan hakhaknya, maka tidak sah wasiat kepada ahli waris (Riwayat al-Tarmizi)". ${ }^{18}$ Namun menurut Fuqaha' Syiah Ja'fariyah menyatakan bahwa wasiat kepada ahli waris yang menerima warisan adalah boleh, kendatipun ahli waris lainnya tidak menyetujuinya. Dasar petunjuk umum (dalalah al-am) Qs. Al-Baqarah, 2:180.

Berbicara mengenai batasan dalam pemberian wasiat dalam islam demi kepentingan ahli waris yang ditinggalkan, seseorang hanya berhak mewasiatkan sebagian kecil dari hartanya. Hal ini dimaksudkan agar wasiat tidak merugikan ahli waris lain yang ditinggalkan. Sesuai dengan hadits Rasulullah SAW yang diriwayatkan oleh Bukhari dan Muslim: 19 "Alangkah baiknya jika manusia mau mengurangi wasiat mereka dari sepertiga menjadi seperempat karena Rasulullah Saw bersabda, "wasiat itu sepertiga, dan sepertiga itupun sudah banyak." Hadits tersebut melarang secara tegas wasiat lebih dari sepertiga harta. Wasiat hanya berlaku dalam batas sepertiga dari harta warisan. Apabila melebihi sepertiga, maka ditangguhkan untuk menunggu persetujuan ahli waris.

Bentuk wasiat menurut Kompilasi Hukum Islam pada Pasal 195 ayat 1 yaitu wasiat dilakukan secara lisan dihadapan dua orang saksi, atau tertulis dihadapan dua orang saksi, atau dihadapan Notaris. ${ }^{20}$ Pada pelaksanaannya pembacaan surat wasiat itu sendiri, seseorang yang akan meninggal memanggil ahli warisnya untuk menyampaikan pesan terakhir atau wasiat agar sepeninggalannya nanti, harta warisannya dibagi dengan cara tertentu, misalnya saja, kepada istri agar diberikan bagian berupa rumah dengan pekarangannya, kepada anak laki-laki sulung diberikan sawah dan untuk anak perempuan diberikan perhiasan dan seterusnya.

Berdasarkan penjelasan di atas yang menjadi ketertarikan penulis untuk mengangkat penelitian ini adalah pembagian warisan melalui wasiat sering kali para ahli waris ada yang merasa dirugikan. Hal itu terjadi cara bagian-bagian yang didapatkannya yang tidak sesuai dengan ketentuan hukum waris. Bahkan dalam pelaksanaan wasiat tersebut tidak sesuai dengan kesepakatan antara para ahli waris. Seperti halnya saja terselip sengketa wasiat dimana Pewaris sebelum meninggal dunia membuat wasiat yang

\footnotetext{
${ }^{18}$ Ahmad Rofiq, Hukum Islam di Indonesia, Jakarta: PT. Raja Grafindo Persada, 2002, hlm. 451.

${ }^{19}$ Dian Khairul Umam, Fiqih Mawaris, Bandung: CV Pustaka Setia, Cet. II, 2006, hlm. 238

${ }^{20}$ Op. Cit., Pasal 195 ayat (1)
} 
di daftarkan di Notaris (Waarmerking) untuk para ahli warisnya yang dalam wasiat itu menginstruksikan untuk membagikan harta peninggalannya yang telah ditentukan oleh si pewaris tersebut dengan menyebutkan nama-nama ahli waris serta bagian-bagian apa saja yang di dapatkan untuk para ahli waris.

Namun terdapat satu warisan berupa tanah dan bangunan yang dijadikan Hotel di daerah Gorontalo diwasiatkan untuk tidak dibagi warisan kepada para ahli waris. Akan tetapi hasil pengelolaan Hotel tersebut dibagi kepada seluruh ahli waris secara adil, pada pelaksanaannya pembagian tersebut tidak dapat berjalan dengan sebagaimana kesepakatan yang telah disepakati oleh para ahli waris atas wasiat tersebut yang mengakibatkan adanya gugatan dari ahli waris yang merasa dirugikan. Oleh karena itu, Bagaimana kedudukan wasiat terhadap hak waris para ahli waris? Dan Bagaimana penyelesaian sengketa wasiat berdasarkan kasus putusan Mahkamah Agung nomor 49 $\mathrm{K} / \mathrm{AG} / 2017$ ?

\section{LANDASAN TEORI}

Adapun teori yang digunakan adalah:

\section{Teori Keadilan}

Dalam Perspektif Islam, keadilan merupaan nilai-nilai moral yang sangat ditekankan dalam Al-Quran. Dalam Al-Quran tidak kurang dari seratus ungkapan yang memasukkan gagasan keadilan, baik dalam bentuk kata-kata yang bersifat langsung ataupun tidak langsung. ${ }^{21}$ Keadilan hukum dalam Islam bersumber dari Tuhan yang Maha Adil, karena pada hakikatnya Allah-lah yang menegakkan keadilan (qaiman bil qisth), maka harus diyakini bahwa Allah tidak berlaku aniaya (zalim) kepada hamba-hambaNya (Q.S. 10/Yunus: 449). Oleh karena itu setiap perbuatan manusia akan dipertanggungjawabkan kepada-Nya pada hari keadilan (Q.S. 4/alNisa: 110).

\section{Teori Maslahah Asas Manfaat/Faedah}

Kemashlahatan yang dapat dijadikan pertimbangan (landasan) untuk menetapkan hukum menurut al-Ghazali adalah apabila:

a. mashlahah itu sejalan dengan jenis tindakan-tindakan syara'

b. mashlahah itu tidak meninggalkan atau bertentangan dengan nash syara'

${ }^{21}$ Majid Khadduri, The Islamic Conception Of Justice, (Maryland: The Jhon Hopkins University Press, 1984) dan terjemahannya oleh G. Mocthar Zoerni dan Joko S.Kahhar, Teologi Keadilan Perspektif Islam, Surabaya: Risalah Gusti, 1999, bab pendahuluan. 
c. mashlahah itu termasuk ke dalam kategori mashlahah yang dhoruri, baik yang menyangkut kemashlahatan pribadi maupun orang banyak dan universal, yaitu berlaku sama untuk semua orang. ${ }^{22}$

\section{KERANGKA KONSEPTUAL}

Acuan dalam penafsiran terhadap konsep beberapa pengertian/istilah., sebagai berikut:

1. Hukum Kewarisan. Hukum Kewarisan adalah hukum yang mengatur tentang pemindahan hak pemilikan harta peninggalan (tirkah) pewaris, menentukan siapasiapa yang berhak menjadi ahli waris dan berapa bagiannya masing-masing. ${ }^{23}$

2. Pewaris. Pewaris adalah orang yang pada saat meninggalnya atau yang dinyatakan meninggal berdasarkan putusan Pengadilan beragama Islam, meninggalkan ahli waris dan hartapeninggalan. ${ }^{24}$

3. Ahli Waris. Ahli Waris adalah orang yang pada saat meninggal dunia mempunyai hubungan darah atau hubungan perkawinan dengan pewaris, beragama Islam dan tidak terhalang karena hukum untukmenjadi ahli waris. ${ }^{25}$

4. Harta Peninggalan. Harta Peninggalan adalah harta yang ditinggalkan oleh pewaris baik yang berupa benda yang menjadi miliknya maupun hak-haknya. ${ }^{26}$

5. Harta Waris. Harta Waris adalah harta bawaan ditambah bagian dari harta bersama setelah digunakan untuk keperluan pewaris selama sakit sampai meninggalnya, biaya pengurusan jenazah (tajhiz), pembayaran hutang dan pemberian untuk kerabat. ${ }^{27}$

6. Wasiat. Wasiat adalah pemberian suatu benda dari pewaris kepada orang lain atau lembaga yang akan berlaku setelah pewaris meninggal dunia. ${ }^{28}$

7. Waarmerking. Waarmerking adalah seseorang memberikan kepada Notaris Akta yang sudah ditanda tangani. Dalam hal ini Notaris tidak lain hanya dapat memberi tanggal waarmerken yang disebut oleh De Bruyn Verklaring van visum dan yang

\footnotetext{
${ }^{22}$ Muhammad Harfin Zuhdi, Formulasi Teori Mashlahah Dalam Paradigma Pemikiran Hukum Islam Kontemporer, Mataram : AIAN Mataram, 1 Desember 2013, hlm. 290, lihat Ibn Manzhur, Lisan al-Arab, hal. 227, lihat Luis Ma'luf, al-Munjid fi al-Luqar wa al-A'lam, hlm. 286.

${ }^{23}$ Pasal 171 (a) Kompilasi Hukum Islam. (Instruksi Presiden R.I Nomor 1 Tahun 1991 tentang Penyebarluasan Kompilasi Hukum Islam).
}

\footnotetext{
${ }^{24}$ Ibid, Pasal 171 (b)

${ }^{25}$ Ibid, Pasal 171 (c)

${ }^{26}$ Ibid, Pasal 171 (d)

${ }^{27}$ Ibid, Pasal 171 (e)

${ }^{28}$ Ibid, Pasal 171 (f)
} 
Otentik's: Jurnal Hukum Kenotariatan (Vol 2, No. 2, Juli 2020)

p-ISSN 2655-5131 e-ISSN 2685-3612

hanya memberi tanggal pasti atau date certain. Maksudnya bahwa Waarmerking merupakan perbuatan pendaftaran perjanjian di bawah tangan pada notaris publik yang penandatanganannya tidak dilakukan dihadapan notaris. ${ }^{29}$

\section{METODE PENELITIAN}

Metode penilitian yang dipergunakan dalam penulisan tesis ini adalah metode penelitian Normatif Yuridis. Metode penelitian normatif adalah penelitian yang meneliti bahan atau data sekunder, sedangkan yuridis adalah mempelajari aturan-aturan yang ada dengan masalah yang diteliti. Dalam penelitian normatif, bahan pustaka yang berupa data dasar yang dalam penelitian digolongkan sebagai data sekunder. Data sekunder bisa mencakup bahan hukum primer, bahan hukum sekunder dan bahan hukum tertier.

\section{HASIL PENELITIAN}

Bila ditelusuri putusan-putusan Mahkamah Agung Nomor 493K/AG/2017 yang membatalkan Putusan Pengadilan Tinggi Agama Gorontalo 6/Pdt.G/2016/PTA.Gtlo atau melakukan koreksi terhadap putusan pengadilan tingkat bawahnya yang dimintakan pemeriksaan kasasi.

Oleh karena itu, putusan Mahkamah Agung yang membatalkan atau memperbaiki putusan pengadilan tingkat bawahnya atas dasar judex facti salah menerapkan hukum. Dalam kaitan ini ada sejumlah yurisprudensi terkait dengan judex facti salah menerapkan hukum, antaranya putusan Mahkamah Agung No. Nomor 493 K/Ag/2017 tanggal 7 Desember 2016 Masehi bertepatan dengan tanggal 7 Rabiulawwal 1438 Hijriah, dengan kaidah hukum:

Judex facti telah salah menerapkan hukum; judex facti dengan melawan hak tidak mempertimbangkan secara cermat alat bukti berupa surat-surat yang diajukan di muka pengadilan. Mahkamah Agung terdapat cukup alasan untuk mengabulkan permohonan kasasi yang diajukan oleh Para Pemohon Kasasi, Amsher Khan Mohamad, dan kawankawan dan membatalkan Putusan Pengadilan Tinggi Agama Gorontalo Nomor 06/Pdt.G/2016/PTA.Gtlo.

Mencermati kaidah hukum dari yurisprudensi di atas, konsekuensinya terjadi pembatalan putusan pengadilan tingkat bawah dan seorang terdakwa harus dibebaskan dari dakwaan Penuntut Umum. Disisi lain, apabila sejak dari awal - dalam pemeriksaan

${ }^{29}$ M.U. Sembiring, Teknik Pembuatan Akta, Medan: Program Pendidikan Spesialis Notaris, Fakultas Hukum, Universitas Sumatera Utara, 1997, hlm 123. 
suatu perkara pada pengadilan tingkat pertama atau pun banding - alat bukti benar-benar dipertimbangkan dengan sempurna, maka tentu seorang terdakwa sudah mendapatkan kebebasannya sejak awal, dimana perbuatan yang dituduhkan kepada terdakwa ternyata bukan merupakan tindak pidana berdasarkan alat bukti yang diajukan dalam persidangan.

Dengan demikian, dalam memeriksaan dan mengadili suatu perkara seharusnya tidak boleh terjadi adanya salah menerapkan hukum. Ini tidak saja karena hukum menjadi dasar pijakan utama dalam memeriksa dan mengadili suatu perkara, namun akibat dari salah menerapkan hukum itu menimbulkan kerugian bagi seorang pencari keadilan, baik moril maupun materiel dalam berbagai aspeknya. Di sisi lain adalah berkenaan dengan kepastian hukum.

Konsep keadilan dalam hukum waris Islam adalah pemberian hak-hak dan kewajiaban kepada setiap orang yang berhak menerimanya. Sebagaimana hikmah pemberian warisan laki-laki yang besarannya adalah dua kali lipat dari harta warisan yang diterima perempuan dikarenakan laki-laki selain membiayai kehidupannya sendiri juga berkewajiban menafkahi keluarganya. Selain itu, keadilan dalam waris Islam juga berlandaskan pada asas keadilan berimbang, sehingga dalam beberapa kasus pembagian harta waris tertentu, bagian perempuan dapat menyamai bagian laki-laki atau melebihinya.

Konsep keadilan yang terdapat dalam Burgerlijk Wetboek dibangun oleh filsafat dan pemikiran-pemikiran Barat, terutama keadilan yang dikemukakan oleh Aristoteles sebagai persamaan hak antara setiap individu. Keadilan pembagian harta warisan dalam BW mengikuti dua dari tiga teori keadilan (keadilan komulatif, keadilan distributif dan keadilan findikatif) yang dikemukakan oleh Aristoteles. Dua teori keadilan yang diterapkan dalam waris BW adalah keadilan komulatif dan keadilan distributif. Keadilan komulatif didefinisikan sebagai perlakuan terhadap seseorang yang tidak melihat jasa yang dilakukannya, yakni setiap orang mendapat haknya. Penerapan keadilan komulatif terlihat dalam pembagian harta warisan yang sama rata tanpa membedakan jenis kelamin dan jasa-jasa pihak tertentu terhadap golongan satu, golongan tiga, dan golongan empat sampai derajat keenam.

Sementara keadilan distributif adalah perlakuan terhadap seseorang sesuai dengan jasanya yang telah dibuat, yakni setiap orang mendapat kapasitas dengan potensi masingmasing. Penerapan keadilan distributif terlihat dalam pembagian harta warisan pada golongan kedua yang mana bagian ayah dan ibu tidak boleh kurang dari seperempat dari harta warisan karena mempertimbangkan jasa keduanya yang sangat besar terhadap 
Otentik's: Jurnal Hukum Kenotariatan (Vol 2, No. 2, Juli 2020)

p-ISSN 2655-5131 e-ISSN 2685-3612

anak-anaknya. Sedangkan teori keadilan Aristoteles yang ketiga yaitu keadilan findikatif tidak diterapkan dalam waris BW karena ia adalah perlakuan terhadap seseorang sebagai balasan kejahatan yang dilakukan.

\section{SIMPULAN}

Kedudukan wasiat terhadap hak waris para ahli waris bahwa surat wasiat dapat dibuat dalam dua cara yakni dinotariskan atau di bawah tangan. Surat wasiat yang dinotariskan (akta wasiat) akan didaftarkan pada Daftar Pusat Wasiat di bawah Kementerian Hukum dan Hak Asasi Manusia. Kekuatan hukum akta wasiat ini tidak dapat dibatalkan secara sepihak melainkan harus melalui putusan pengadilan. Wasiat yang melalui akta wasiat lebih menjamin secara hukum, baik bagi yang mengeluarkan wasiat maupun bagi yang menerima wasiat.

Mahkamah Agung dalam penanganan kasus sengketa hak waris dengan putusan No. 493K/AG/2017, bahwa tindakan hakim Mengabulkan permohonan kasasi dari Para Pemohon Kasasi: 1. Amsher Khan Mohamad, 2. Ferry Mohamad. dan 3. Mirdawaty Mohamad tersebut; memang tidak salah. Dengan vonis ini, memang terdapat cukup alasan untuk mengabulkan permohonan kasasi yang diajukan oleh Para Pemohon Kasasi, namun kurang kemanfaatan dan mengandung nilai-nilai keadilan. Karena Putusan Hakim yang berkualitas tidak lain putusan yang dapat mewujudkan keadilan atau putusan yang mencerminkan rasa keadilan yang dapat dilaksanakan dan dapat diterima atau memuaskan keadilan bagi penggugat maupun tergugat.

\section{Saran}

Dalam rangka mencapai kepastian hukum khususnya mengenai wasiat, sebaiknya diterbitkan peraturan yang mewajibkan pejabat pembuat surat keterangan ahli waris mengecek adanya wasiat sebelum membuat surat keterangan ahli waris sehingga tidak terjadi pembagian warisan tanpa pemeriksaan adanya wasiat terlebih dahulu.

Dalam pembuatan testament, notaris hendaklah menjelaskan kepada pembuat testament untuk menunjuk seorang pelaksana wasiat yang mengetahui adanya wasiat dan mewajibkan kepada penerima wasiat untuk memberitahukan keberadaan surat wasiat tersebut. Ahli waris ab intestato dan ahli waris testamenter sebaiknya mencari solusi terbaik atas sengketa pembagian warisan ini. Selain untuk menghemat biaya dan waktu, upaya hukum non litigasi ini sangat diperlukan untuk tetap menjaga ikatan persaudaraan dan kekeluargaan diantara para ahli waris. 


\section{DAFTAR PUSTAKA}

\section{Buku}

Ahmad Rofiq, Hukum Islam di Indonesia, Jakarta: PT. Raja Grafindo Persada, 2002.

Amir Syarifuddin, Pelaksanaan Hukum Kewarisan Islam Dalam Lingkungan Adat Minangkabau, Jakarta: PT. Gunung Agung, 1990

Hukum Kewarisan Islam, Cet.I, Jakarta: Preneda Media, 2004.

Asyhari Abta, Djunaidi Syakur, Ilmu Waris Deskripsi Islam Praktis Dan Terapan, Surabaya: Pustaka Hikmah Perdana, 2005

Asafri Jaya Bakri, Konsep Maqasid Syari'ah Menurut al-Syatibi, Jakarta: PT, Raja Grafindo Persada, 1996.

Departemen Agama RI, Al-Qur'an dan terjemahan, Bandung: CV Diponegoro, 2010.

Dian Khairul Umam, Fiqih Mawaris, Bandung: CV Pustaka Setia, Cet. II, 2006.

H. Salim Bahreisy, H sahid Bahreisy, Terjemah Tafsir Ibnu Katsir, Jilid 1, Surabaya: PT. Bina Ilmu, 2002.

Hasniah Hasan, Hukum Warisan Dalam Islam, Jakarta: PT. Bina Ilmu, 2000.

Hasniah Hasan, Hukum Waris Dalam Islam, Bandung: PT Bina Ilmu, 1987.

Ismail Haqiy Al-Burusawa, Tafsir Ruhul Bayan Juz 1, Lebanon: Dar al Fiqr, 2006.

M. Hasballah Thaib, Ilmu Hukum Waris Islam, Medan: MKn USU, 2009

Masjfuk Zuhdi, Masail Fiqhiyah (Kapita Selekta Hukum Islam), Jakarta : PT. Gunung Agung, 1996.

Majid Khadduri, The Islamic Conception Of Justice, (Maryland: The Jhon Hopkins University Press, 1984)

Mukhlis Lubis, Ilmu Pembagian Waris, Medan: Pesantren Al Manar, 2011.

Muhammad Ali as Shabuni, Hukum Waris Dalam Syariat Islam, Bandung: CV Diponegoro, 2010.

Muhammad Harfin Zuhdi, Formulasi Teori Mashlahah Dalam Paradigma Pemikiran Hukum Islam Kontemporer, Mataram : AIAN Mataram, 1 Desember 2013.

M.U. Sembiring, Teknik Pembuatan Akta, Medan: Program Pendidikan Spesialis Notaris, Fakultas Hukum, Universitas Sumatera Utara, 1997.

Idris Ramulyo, Hukum Kewarisan Islam (Studi Kasus Perbandingan Ajaran Syafi'IPatrilineal-Hazairin-Bilateral- dan Praktek di Pwngadilan Agama, Ind Hill Co, 2010.

Sayid Sabiq, Fikih Sunnah, Bandung : PT. Al-Ma'arif, 1988.

Sayid Sabiq, Fikih Sunnah, Bandung: PT. Al-Ma'arif, 1990.

\section{Peraturan Perundang-undangan}

Undang-Undang Dasar Negara Republik Indonesia Tahun 1945

Undang-Undang Nomor 2 tahun 2014 tentang Perubahan atas Undang-Undang Nomor 30

Tahun 2004 Tentang Jabatan Notaris

Instruksi Presiden R.I Nomor 1 Tahun 1991 tentang Kompilasi Hukum Islam. 
Otentik's: Jurnal Hukum Kenotariatan (Vol 2, No. 2, Juli 2020)

p-ISSN 2655-5131 e-ISSN 2685-3612

Peraturan Pemerintah Republik Indonesia Nomor 37 Tahun 1998 Tentang Peraturan Jabatan Pejabat Pembuat Akta Tanah.

Peraturan Pemerintah Nomor 24 Tahun 1997 tentang Pendaftaran Tanah Petikan Putusan Mahkamah Agung Nomor 493 K/Ag/2017

Petikan Putusan Pengadilan Tinggi Agama Gorontalo Nomor 6/Pdt.G/2016/PTA.Gtlo

Petikan Putusan Pengadilan Agama Gorontalo Nomor 0382/Pdt.G/2015/PA.Gtlo.

\section{Jurnal/Makalah}

Herlien Budiono, Menuju Keterangan Hak Waris Yang Uniform (Wacana Pembuktian Sebagai Ahli Waris Dengan Akta Notaris). Kongres XX - Pembekalan Dan Penyegaran Pengetahuan Ikatan Notaris Indonesia. Surabaya. 2009.

Syahril Sofyan, Sentuhan Jasa Notaris Dalam Penyelesaian Warisan, Pertemuan INI Pengda Medan, Medan. 2015.

R.M. Henky Wibawa, Bambang Pramana, Suhariningsih dan Abdul Rachmad Boediono, Analisis Yuridis Surat Keterangan Waris Sebagai Alat Bukti, Fakultas Hukum Universitas Brawijaya, 2012.

R. Soerojo Wongsowidjojo, Inventarisasi Masalah Hukum Waris Dalam Praktek, Makalah pada Simposium Hukum Waris Nasional. BPHN. 1989.

\section{Media Elektronik}

“Legalisasi dan Waarmerking”,(25 Mei 2018), terdapat disitus http://irmadevita.com 